Gut, 1986, 27, 1362-1368

\title{
Serum immunoreactive cationic trypsinogen: a useful indicator of severe exocrine dysfunction in the paediatric patient without cystic fibrosis
}

\author{
D J MOORE, G G FORSTNER, C LARGMAN, G J CLEGHORN,
} S S WONG, AND P R DURIE

From the Division of Gastroenterology, Department of Pediatrics and the Research Institute, The Hospital for Sick Children, the Department of Pediatrics, University of Toronto, Toronto, Ontario, Canada and the

Biochemistry Research Laboratory, VA Medical Centre, Martinez, and Department of Biological Chemistry, University of California, Davis School of Medicine, Davis, California, USA

SUMmARY We evaluated serum cationic trypsinogen as a marker of exocrine pancreatic function in children without cystic fibrosis. The ability of this test to determine steatorrhoea of pancreatic origin, and its relationship to a wide range of exocrine pancreatic function were assessed. Serum trypsinogen was measured in 32 children with steatorrhoea, 10 with pancreatic and 22 with nonpancreatic causes. In patients with pancreatic steatorrhoea, serum cationic trypsinogen was $4.9 \pm 4.9 \mu \mathrm{g} / \mathrm{l}($ mean $\pm \mathrm{SD})$, significantly below values in patients with non-pancreatic steatorrhoea $(47 \cdot 0 \pm 22 \cdot 1 \mu \mathrm{g} / \mathrm{l}, \mathrm{p}<0 \cdot 001)$ and 50 control subjects $(31 \cdot 4 \pm 7 \cdot 4 \mu \mathrm{g} / \mathrm{l}, \mathrm{p}<0 \cdot 001)$. Serum cationic trypsinogen values in patients with pancreatic steatorrhoea all fell below the lower limit of our control range and below all values for patients with non-pancreatic steatorrhoea. Serum cationic trypsinogen was also evaluated against pancreatic trypsin output in 47 patients (range $0 \cdot 2-17 \cdot 0 \mathrm{yr}$ who underwent a hormonal pancreatic stimulation test. In 17 patients, serum cationic trypsinogen was low $(<-2 \mathrm{SD}$ or $<16.6 \mu \mathrm{g} / \mathrm{l})$, and associated with greatly impaired pancreatic trypsin output, ranging from $0-8 \%$ of mean normal trypsin output. Five of these 17 patients did not have steatorrhoea. In 30 patients with normal or raised serum cationic trypsinogen $(\geq 16 \cdot 6$ $\mu \mathrm{g} / \mathrm{l})$, pancreatic trypsin output ranged from $15-183 \%$ of mean normal values. In conclusion, low serum cationic trypsinogen suggests severely impaired exocrine pancreatic function, with sensitivity extending above the steatorrhoeic threshold. In the presence of steatorrhoea, low serum cationic trypsinogen indicates a pancreatic aetiology. Normal serum cationic trypsinogen, however, does not exclude impaired pancreatic function, above the steatorrhoeic threshold.

Exocrine pancreatic function is difficult to assess because of the inaccessibility of the pancreas and its secretions. To measure and analyse exocrine pancreatic secretions directly and accurately, quantitative aspiration of duodenal secretions in conjunction with some form of pancreatic secretory stimulation is required. Although this approach is invasive and time consuming, it remains the most sensitive means of accurately assessing pancreatic function. A variety of less invasive, less sensitive tests of pancreatic

Address for correspondence: Dr P R Durie, Division of Gastroenterology, Department of Pediatrics. The Hospital for Sick Children, 555 University Avenue. Toronto, Ontario, Canada M5G 1 X8.

Received for publication 14 February 1986. function are available, but have been incompletely evaluated in children. ${ }^{1-4}$ As a simple, non-invasive test of pancreatic function, the measurement of a number of pancreatic enzymes in the serum has been pursued. ${ }^{5-8}$ We have been particularly interested in the measurement of serum immunoreactive pancreatic cationic trypsinogen, as a marker of exocrine pancreatic dysfunction in children. Serum cationic trypsinogen when low, is known to be associated with reduced pancreatic exocrine function in a number of disorders, including Shwachman's syndrome ${ }^{59}$ and type 1 diabetes mellitus. ${ }^{10}$ In cystic fibrosis, however, the commonest cause of pancreatic insufficiency in the paediatric age group, ${ }^{11}$ serum cationic trypsinogen values are 
usually raised in infancy and early childhood, and not a reliable indicator of the level of pancreatic function until after the age of 5-7 years. ${ }^{12} 13$

Jacobson et al ${ }^{14}$ have shown that serum cationic trypsinogen can be used to distinguish pancreatic steatorrhoea from steatorrhoea because of a nonpancreatic aetiology in adults with malabsorption. As children with failure to thrive may or may not have steatorrhoea, a simple biochemical test which might direct clinical investigation toward the precise aetiology would be most desirable. We have therefore set out to examine the specificity of serum cationic trypsinogen for steatorrhoea of pancreatic origin in children without cystic fibrosis. In addition, the relationship of serum cationic trypsinogen to a wide range of exocrine pancreatic function was examined in a number of children who underwent a quantitative pancreatic stimulation test.

\section{Methods}

PATIENTS

SERUM CATIONIC TRYPSINOGEN IN PANCREATIC AND NON-PANCREATIC STEATORRHOEA

We studied 32 patients (mean age $3 \cdot 1$ years, range $0 \cdot 2-17 \cdot 0$ years), with documented steatorrhoea. Patients with cystic fibrosis or renal impairment were excluded. Fat balance studies involved a three to five day stool collection, accurate weighing and recording of dietary fat intake and subsequent analysis of faecal fat losses using the method of van der Kamer. ${ }^{15}$ Patients were considered to have significant steatorrhoea if faecal fat losses exceeded $7 \%$ of dietary fat intake in patients over 6 months of age, or were greater than $15 \%$ of dietary fat intake in infants less than 6 months of age. ${ }^{16}$ Further investigations to determine the exact aetiology of steatorrhoea included jejunal suction biopsies in 24 patients and quantitative pancreatic stimulation tests in 18 patients.

The clinical diagnoses of the 32 steatorrhoeic patients are listed in Table 1. Ten patients (mean age 5.9 years, range $0.3-17.0$ years) with severe pancreatic insufficiency on quantitative pancreatic stimulation testing were allocated to the group with pancreatic steatorrhoea. This group included a 14 year old boy with biopsy proven coeliac disease, who failed to grow and gain weight adequately after 12 months on a strict gluten free diet. Subsequent quantitative pancreatic stimulation testing, showed the rare association of coeliac disease and severe exocrine pancreatic dysfunction. ${ }^{17}$ Also, a $2 \cdot 8$ year old boy with insulin dependent diabetes mellitus presented in acute ketoacidosis, who three months after presentation was found to have steatorrhoea when he failed to gain weight. In view of the known association between insulin dependent diabetes mellitus and impaired exocrine pancreatic function, ${ }^{10} 18$ we subsequently did a quantitative pancreatic stimulation test which demonstrated pancreatic function below the threshold for steatorrhoea. This patient had a good clinical response to pancreatic enzyme supplements.

Twenty two patients (mean age 1.8 years, range $0 \cdot 2-4.8$ years) had a non-pancreatic cause for steatorrhoea. Nineteen of these patients had a biopsy proven enteropathy, 12 of whom had coeliac disease. In one patient, severe cholestasis was present. Two patients in this group had no demonstrable cause for steatorrhoea, but had normal pancreatic function on pancreatic stimulation testing.

\section{SERUM CATIONIC TRYPSINOGEN AND EXOCRINE}

PANCREATIC FUNCTION

Exocrine pancreatic function was evaluated by a quantitative pancreatic stimulation test in 47 patients (mean age 4.5 years, range 0.2 to 17.0 years), with suspected pancreatic dysfunction. Patients with cystic fibrosis and renal impairment were excluded. Table 2 lists the underlying diagnoses in these patients. Shwachman's syndrome $(n=13)$ represented the largest diagnostic category of

Table 1 Patients with steatorrhoea

\begin{tabular}{|c|c|c|c|}
\hline \multicolumn{2}{|l|}{ Pancreatic steatorrhoea } & \multicolumn{2}{|l|}{ Non-pancreatic steatorrhoea } \\
\hline Diagnosis & $n$ & Diagnosis & $n$ \\
\hline Shwachman's syndrome & 7 & Coeliac disease & 12 \\
\hline Diabetes mellitus type 1 & 1 & Post enteritis enteropathy & 5 \\
\hline Idiopathic & 1 & Hypogammaglobulinemia/ & \\
\hline \multirow{4}{*}{ Coeliac disease/pancreatic insufficiency } & 1 & Villus atrophy (unknown aetiology) & 1 \\
\hline & & Congenital villus atrophy & 1 \\
\hline & & Cholestasis & 1 \\
\hline & & No diagnosis* & 2 \\
\hline
\end{tabular}

${ }^{*}$ Quantitative pancreatic stimulation test normal. 
Table 2 Patients undergoing a pancreatic stimulation test

\begin{tabular}{lr}
\hline Diagnosis & $n$ \\
\hline Failure to thrive* & 17 \\
Shwachman's syndrome & 13 \\
Postenteritis enteropathy & 4 \\
Islet cell hyperplasia (95\% pancreatectomy) & 3 \\
Coeliac disease & 3 \\
Short gut & 1 \\
Polyendocrinopathy and T cell dysfunction & 1 \\
Congenital villus atrophy & 1 \\
Gastroesophageal reflux with failure to thrive & 1 \\
Idiopathic pancreatic insufficiency & 1 \\
Diabetes mellitus type 1/pancreatic insufficiency & 1 \\
Cholestasis & \\
Total & 47 \\
\hline
\end{tabular}

*Failure to thrive - no organic basis.

patients undergoing a pancreatic stimulation test. Eighteen of the 47 patients who underwent a pancreatic stimulation test had steatorrhoea and these subjects were included in the analysis of steatorrhoeic patients (see above).

A quantitative pancreatic stimulation test was carried out according to a previously described method. ${ }^{19}$ There were four, 20 minute collection periods, comprising a baseline equilibration period, followed by three stimulated periods during which secretin and cholecystokinin were infused. Duodenal juice was analysed for trypsin activity using the titrimetric method of Dyck. ${ }^{20}$ Stimulated trypsin output was then quantified using a correction factor ${ }^{19}$ calculated from the fractional recovery of an infused non-absorbable marker. ${ }^{21}$ Trypsin output was expressed in units per kilogram body weight per hour $(\mathrm{U} / \mathrm{kg} / \mathrm{h})$. We have established normal pancreatic trypsin output in 17 well nourished patients and volunteers at $2274 \pm 986 \mathrm{U} / \mathrm{kg} / \mathrm{h}($ mean $\pm \mathrm{SD})$, range $1193-3960 \mathrm{U} / \mathrm{kg} / \mathrm{h}$.

\section{SERUM CATIONIC TRYPSINOGEN}

Blood samples were collected during the baseline period of the quantitative pancreatic stimulation test, or at the time of a three to five day fat balance study in the 14 patients who did not undergo a pancreatic stimulation test. Samples were separated by centrifugation and sera stored at $-70^{\circ} \mathrm{C}$ until analysed. Serum cationic trypsinogen was measured using a double antibody radioimmunoassay. ${ }^{22} \mathrm{We}$ have established normal values for serum cationic trypsinogen in 50 well nourished subjects $(5 \cdot 7 \pm 5 \cdot 6$ years (mean $\pm S D$ ), range $0 \cdot 2-17 \cdot 0$ years), with no clinical evidence of gastrointestinal, pancreatic or renal pathology, $31.4 \pm 14.8 \mu \mathrm{g} / \mathrm{l}$ (mean $\pm 2 \mathrm{SD}$ ), range $16.9-57.7 \mu \mathrm{g} / \mathrm{l})$. In these subjects, linear regression analysis showed no age related changes in serum cationic trypsinogen values.

Serum cationic trypsinogen was also measured using a commercially available kit (Cis Trypsik: Damon Diagnostics, Needham Heights, Mass, USA manufacturer Sorin Biomedia, Saluggia, Italy), in 42 of the 47 patients who underwent a pancreatic stimulation test.

\section{STATISTICAL ANALYSIS}

Data for serum cationic trypsinogen and pancreatic trypsin output were expressed as the mean and one standard deviation. Data were compared using the unpaired Student's $t$ test with and without $\log$ transformation, as some of the data were not normally distributed. Analysis is shown for untransformed data as the differences were highly significant using both methods, although significance was greater using log transformed data. We compared our laboratory assay for serum cationic trypsinogen and the commercial kit using linear regression analysis.

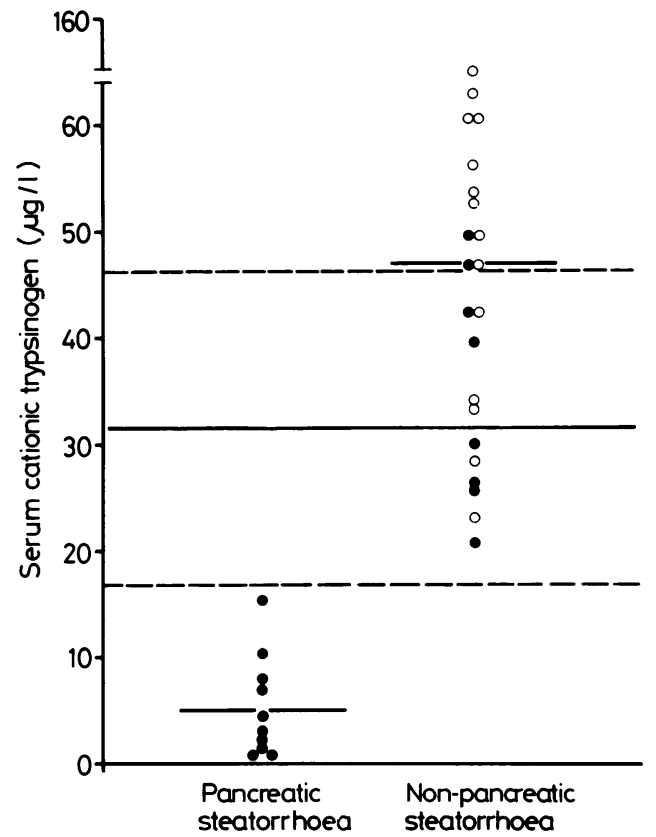

Fig. 1 Serum cationic trypsinogen values in patients with pancreatic and non-pancreatic steatorrhoea. The solid and interrupted horizontal lines indicate mean normal cationic trypsinogen $\pm 2 S D$ respectively $(31 \cdot 4 \pm 14 \cdot 8 \mu \mathrm{g} / \mathrm{l})$.

patients who underwent a pancreatic stimulation test. $\bigcirc$; patients with non-pancreatic steatorrhoea who did not have a pancreatic stimulation test. 


\section{Results}

SERUM CATIONIC TRYPSINOGEN IN PANCREATIC AND NON-PANCREATIC STEATORRHOEA

Serum cationic trypsinogen values in patients with pancreatic and non-pancreatic steatorrhoea are shown in Figure 1. Mean serum cationic trypsinogen in the patients with pancreatic steatorrhoea $(4.9 \pm 4.9 \mu \mathrm{g} / \mathrm{l})$ was significantly below the mean value in 22 patients with non-pancreatic steatorrhoea $(47 \cdot 0 \pm 22 \cdot 1 \mu \mathrm{g} / \mathrm{l}, \mathrm{p}<0 \cdot 001)$ and also the control subjects $(31.4 \pm 7.4 \mu \mathrm{g} / \mathrm{l}, \mathrm{p}<0.001)$. There was no overlap in individual serum cationic trypsinogen values between those patients with pancreatic steatorrhoea (range $0-15.0 \mu \mathrm{g} / \mathrm{l}$ ) and either the normal control range $(16.9-57.7 \mu \mathrm{g} / \mathrm{l})$ or the 22 patients with non-pancreatic steatorrhoea (20.6$111.5 \mu \mathrm{g} / \mathrm{l})$. Mean serum cationic trypsinogen in the group with non-pancreatic steatorrhoea was also significantly higher than that of the control group $(\mathrm{p}<0 \cdot 01)$.

\section{SERUM CATIONIC TRYPSINOGEN AND PANCREATIC} EXOCRINE FUNCTION

Serum cationic trypsinogen values plotted against pancreatic trypsin output in the 47 patients who had a quantitative pancreatic stimulation test are shown in Figure 2. Although no clinically useful linear or curvilinear relationship was found, low serum cationic trypsinogen values were associated with low pancreatic trypsin output, while normal or high serum cationic trypsinogen values were associated with higher levels of pancreatic trypsin output over a wide range. Further analysis of the pancreatic stimulation test data is shown in Table 3 , where the patients were divided into two groups on the basis of serum cationic trypsinogen values. Mean pancreatic trypsin output in 17 patients with low serum cationic trypsinogen values $(<16.6 \mu \mathrm{g} / \mathrm{l})$ was $52 \pm 53(\mathrm{U} / \mathrm{kg} / \mathrm{h}$, significantly below mean output in 30 patients with normal or high serum cationic trypsinogen

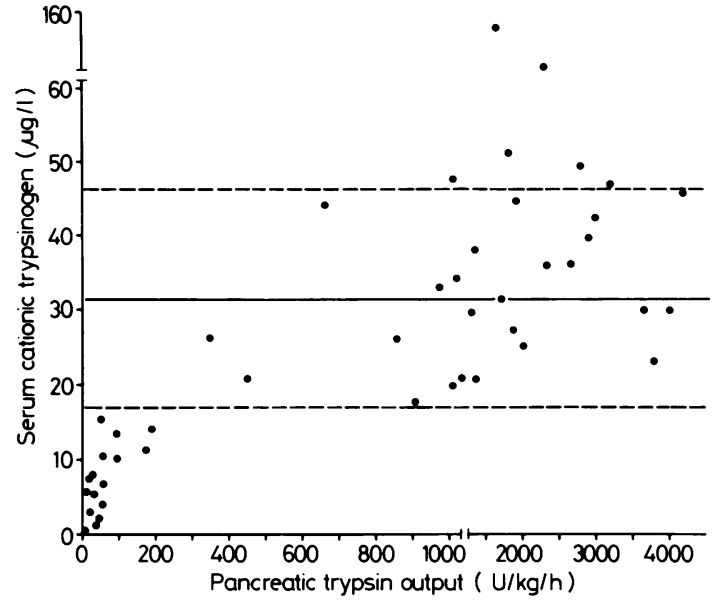

Fig. 2 Serum cationic trypsinogen plotted against pancreatic trypsin output. The solid and interrupted lines indicate mean normal cationic trypsinogen $\pm 2 S D$ respectively $(31 \cdot 4 \pm 14 \cdot 8 \mu \mathrm{g} / \mathrm{l}$. Low serum cationic trypsinogen $(<16.6 \mu \mathrm{g} / \mathrm{l})$ was associated with severely impaired pancreatic trypsin output $(<181 \mathrm{U} / \mathrm{k} / \mathrm{h})$, while normal or high serum cationic trypsinogen $(\geq 16.6 \mu \mathrm{g} / \mathrm{l})$, was associated with higher trypsin outputs (343-4159 $U / \mathrm{kg} / \mathrm{h})$, which extended over a wide range.

$(1922 \pm 1085 \mathrm{U} / \mathrm{kg} / \mathrm{h}, \mathrm{p}<0 \cdot 001)$. Pancreatic trypsin output in the group with low serum cationic trypsinogen ranged from $0-181 \mathrm{U} / \mathrm{kg} / \mathrm{h}$ or $0 \cdot 8 \%$ of mean normal trypsin output, while in patients with normal or high serum cationic trypsinogen, there was a wide range of function from $343-4159 \mathrm{U} / \mathrm{kg} / \mathrm{h}$ or $15-183 \%$ of mean normal values. There was no overlap in individual values for pancreatic trypsin output between the two groups.

It is evident that six patients had raised serum cationic trypsinogen values (Fig. 2). We therefore compared pancreatic trypsin output in patients with normal serum cationic trypsinogen $(n=24)$ and

Table 3 Pancreatic trypsin output in patients with low or normal/high serum cationic trypsinogen

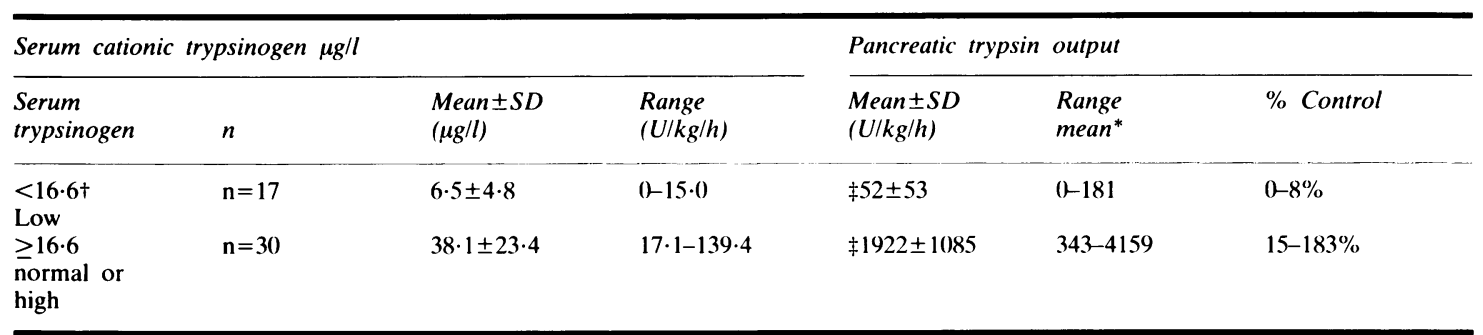

${ }^{*}$ Trypsin output in control patients; $2274 \pm 986 \mathrm{U} / \mathrm{kg} / \mathrm{h}($ mean $\pm \mathrm{SD})$.

$\dagger 16.6 \mu \mathrm{g} / \mathrm{l}$, lower limit of normal serum cationic trypsinogen $(31 \cdot 4 \pm 14 \cdot 8 \mu \mathrm{g} / \mathrm{l}$, mean $\pm 2 \mathrm{SD})$. $\neq \mathrm{p}<0 \cdot 001$. 
patients with raised serum cationic trypsinogen $(n=6)$. Pancreatic trypsin output in the patients with normal serum cationic trypsinogen $(1878 \pm 1156 \mathrm{U} /$ $\mathrm{kg} / \mathrm{h}$, range $343-4159 \mathrm{U} / \mathrm{kg} / \mathrm{h}$ ) was not significantly different from that of patients with raised serum cationic trypsinogen values $(2103 \pm 797 \mathrm{U} / \mathrm{kg} / \mathrm{h})$, range $1013-3170 \mathrm{U} / \mathrm{kg} / \mathrm{h}$ ).

Fifteen of 17 patients with low serum cationic trypsinogen underwent three to five day fat balance studies. Ten of these patients had steatorrhoea, while five had normal fat absorption. Table 4 compares serum cationic trypsinogen and the range of pancreatic trypsin output in those with and without steatorrhoea. No statistically significant difference in serum cationic trypsinogen values was found between those with steatorrhoea $(4.9 \pm 4.9$ $\mu \mathrm{g} / \mathrm{l})$ and the group without steatorrhoea $(10 \cdot 7 \pm 3 \cdot 5$ $\mu \mathrm{g} / \mathrm{l})$. Values, however, tended to be lower in the steatorrhoeic patients, and with more data, differences may become significant. Patients with steatorrhoea, had pancreatic trypsin outputs ranging from $0-2 \%$ of mean normal trypsin output, while patients without steatorrhoea, had trypsin outputs ranging from $1-8 \%$ of mean normal trypsin output. Thus low serum cationic trypsinogen detected patients with impaired pancreatic function above the steatorrhoeic threshold.

COMPARISON WITH THE COMMERCIAL IMMUNOREACTIVE TRYPSINOGEN ASSAY

Our laboratory radioimmunoassay was also compared with data obtained using the Sorin assay for determining serum cationic trypsinogen. In the 42 patient samples available for comparison, mean serum trypsinogen was $29 \cdot 1 \pm 25 \cdot 2 \mu \mathrm{g} / \mathrm{l}$ for our assay and $29.2 \pm 32.3 \mu \mathrm{g} / \mathrm{l}$ for the commercial assay. Regression analysis of the commercial assay values on our values revealed a highly significant correlation $(\mathrm{r}=0.93, \mathrm{p}<0.001 ; \mathrm{X}=-5.42+1.19 \mathrm{Y})$. The standard error around the regression line was 11.93 , which amounts to a standard error around the

Table 4 Pancreatic trypsin output in patients with low serum cationic trypsinogen with and without steatorrhoea

\begin{tabular}{|c|c|c|c|c|}
\hline Serum cationic & \multicolumn{2}{|c|}{ trypsinogen $<16.6 \mu g / l$} & \multicolumn{2}{|c|}{$\begin{array}{l}\text { Pancreatic trypsin } \\
\text { output }\end{array}$} \\
\hline Steatorrhoea & $n$ & Mean $\pm S D \mu g / l$ & $U / \mathrm{kg} / \mathrm{h}$ & $\begin{array}{l}\% \text { Control } \\
\text { mean* }\end{array}$ \\
\hline Yes & $<10$ & $+4.9 \pm 4.9$ & $0-51$ & $0-2$ \\
\hline No & $<5$ & $\dagger 10 \cdot 7 \pm 3 \cdot 5$ & $27-181$ & $1-8$ \\
\hline
\end{tabular}

${ }^{*}$ Trypsin output in normal control patients; $2274 \pm 986 \mathrm{U} / \mathrm{kg} / \mathrm{h}$ $($ mean \pm SD).

$+\mathrm{p}<0 \cdot 1$, NS. predicted mean of approximately three. The Sorin assay also reliably distinguished patients with steatorrhoea due to a pancreatic cause from those with fat malabsorption because other causes. In eight patients with pancreatic steatorrhoea, mean serum cationic trypsinogen was $3 \cdot 0 \pm 4 \cdot 9 \mu \mathrm{g} / \mathrm{l}$ significantly below the mean value in 8 patients with nonpancreatic steatorrhoea $37 \cdot 2 \pm 17 \cdot 3 \mu \mathrm{g} / \mathrm{l}(\mathrm{p}<0 \cdot 001)$. Again, there was no overlap in serum cationic trypsinogen values between the patients with pancreatic and non-pancreatic steatorrhoea.

\section{Discussion}

In paediatric practice, malabsorption or suspected malabsorption is a frequently encountered clinical problem. Steatorrhoea is, of course, a non-specific finding and further evaluation is necessary to determine the precise aetiology of the malabsorption. In the absence of clinical manifestations of cholestasis, the presence of fat malabsorption generally questions the status of the exocrine pancreas versus small intestinal integrity. Once cystic fibrosis has been excluded by a normal sweat chloride, further evaluation may require relatively invasive investigations such as a small bowel biopsy or a quantitative pancreatic stimulation test, or both. We have therefore explored the ability of serum cationic trypsinogen to help direct investigations of patients with steatorrhoea, toward a pancreatic or nonpancreatic aetiology. We have shown, that all patients with pancreatic steatorrhoea had abnormally low serum cationic trypsinogen levels, which clearly distinguished them from normal controls and patients with non-pancreatic steatorrhoea. Measurement of serum cationic trypsinogen appears to offer a rapid and specific means of defining a pancreatic or non-pancreatic aetiology for steatorrhoea. This study confirms, therefore, in a paediatric population, the overall findings of Jacobsen et al, ${ }^{14}$ who demonstrated the value of serum trypsinogen in the diagnosis of steatorrhoea of pancreatic origin in adults.

We have been able to evaluate the sensitivity of serum cationic trypsinogen in children who underwent a quantitative pancreatic stimulation test. The children we investigated had a wide range of exocrine pancreatic function as indicated by pancreatic trypsin outputs ranging from $0-183 \%$ of our mean normal values. On the basis of these data, serum cationic trypsinogen appeared to reliably indicate pancreatic dysfunction, only if severe impairment of exocrine pancreatic function existed. In children with low serum cationic trypsinogen levels, pancreatic trypsin outputs ranged from $0-8 \%$ of our mean normal values (Table 3 ). It should be empha- 
sised, however, that some patients with normal serum cationic trypsinogen levels also had diminished exocrine function, as low as $15 \%$ of our mean normal values. Low serum cationic trypsinogen was therefore capable of detecting patients with severely compromised exocrine pancreatic function, but the presence of a normal serum level did not exclude diminished exocrine pancreatic function.

We previously demonstrated that when pancreatic exocrine function is expressed in terms of pancreatic lipase and colipase output, enzyme output must be reduced by approximately $98 \%$ and $99 \%$ respectively of mean normal values, before pancreatic steatorrhoea develops. ${ }^{23}$ Of interest, in 10 patients with pancreatic steatorrhoea included in this study, pancreatic trypsin output ranged from $0-2 \%$ of mean normal pancreatic trypsin values (Table 4), an identical range to that established for lipase and colipase. ${ }^{23}$ All patients with pancreatic steatorrhoea had serum cationic trypsinogen levels below the normal range. There were five patients with low serum cationic trypsinogen levels who had normal fat absorption, and pancreatic trypsin outputs ranged from $1-8 \%$ of mean normal values (Table 4 ). Lipase and colipase output in these five patients were within a similar range (data not shown), but above the threshold for developing steatorrhoea. ${ }^{23}$ Thus, low serum cationic trypsinogen appeared sensitive enough to detect patients in whom pancreatic function had not deteriorated to the point of producing fat malabsorption, but who nevertheless had severely compromised exocrine pancreatic function.

Some of the patients included in this study had raised serum cationic trypsinogen levels. All these patients were moderately or severely malnourished (observed weight $<85 \%$ or $<75 \%$ respectively of ideal weight) when evaluated by the anthropometric criteria of McLaren and Read. ${ }^{24}$ Raised serum cationic trypsinogen values in acutely malnourished children has been the subject of a previous report from our laboratory. ${ }^{25}$ We speculated that raised serum cationic trypsinogen values in acute malnutrition may indeed be a reflection of pancreatic injury. Of interest, pancreatic exocrine function, based upon pancreatic trypsin output, ranged from 45$139 \%$ of mean normal values. Pancreatic functional capacity in these malnourished children, therefore, appeared to be well preserved, but the small number of malnourished children studied to date precludes complete evaluation of this interesting observation.

Patients with cystic fibrosis were deliberately excluded, because of our previous observation of raised serum trypsinogen levels in infancy and early childhood. ${ }^{12} 13$ High serum cationic trypsinogen in these patients, could be due to pancreatic ductal obstruction and regurgitation of enzymes into the circulation, because the highest levels of circulating cationic trypsinogen were found in infants with absent duodenal trypsin output following direct pancreatic stimulation testing. ${ }^{5}$ Our cross sectional data revealed that serum cationic trypsinogen levels declined with advancing age reaching subnormal values by 5-7 years of age in the steatorrhoeic patients with pancreatic insufficiency. ${ }^{12} 13$ On the other hand, cystic fibrosis patients with adequate exocrine pancreatic function for normal fat absorption, maintained normal or raised serum levels regardless of age. ${ }^{12} 13$ This test, therefore, does appear to be of value as an indicator of exocrine pancreatic dysfunction in cystic fibrosis, but only after 5-7 years of age.

In conclusion, in the absence of cystic fibrosis, determination of serum cationic trypsinogen is an extremely useful and specified method of delineating a pancreatic or non-pancreatic aetiology of fat malabsorption in infancy and childhood. Our data also indicate that patients with low serum cationic trypsinogen levels will have severely compromised exocrine pancreatic function not necessarily at a level severe enough to produce steatorrhoea. This test seems capable of detecting diminished pancreatic function below or equal to $8 \%$ of mean normal pancreatic trypsin output. With the availability of simple commercial kits for measuring serum cationic trypsinogen, this technique could be introduced as a useful biochemical method for identifying children with severe loss of exocrine pancreatic function.

This work was presented in part at the annual meeting of the American Gastroenterological Association in New York, NY 11-17 May, 1985. Supported by a research grant (MA-6752) from the Medical Research Council of Canada. Drs Moore and Cleghorn were recipients of research fellowships from the Canadian Cystic Fibrosis Foundation.

\section{References}

1 Watkins JB, Klein PD, Schoeller DA, Kirschner BS, Park R, Perman JA. Diagnosis and differentiation of fat malabsorption in children using ${ }^{13} \mathrm{C}$-labelled lipids: trioctanoin, triolein, and palmitic acid breath tests. Gastroenterology 1982; 82: 911-7.

2 Lankisch PG, Schreiber A, Otto J. Pancreolauryl Test. Evaluation of a tubeless pancreatic function test in comparison with other indirect and direct tests for exocrine pancreatic function. Dig Dis Sci 1983; 28: 490-3.

3 Brugge WR, Goff JS, Allen NC, Podell ER, Allen RH. Development of a dual label Schilling test for pancreatic exocrine function based on the differential absorp- 
tion of cobalamin bound to intrinsic factor and $\mathrm{R}$ protein. Gastroenterology 1980; 78: 937-49.

4 Toskes PP. The Bentiromide test for pancreatic exocrine insufficiency. Pharmacotherapy 1984; 4: 74-80.

5 Durie PR, Largman C, Brodrick JW, et al. Plasma immunoreactive pancreatic cationic trypsinogen in cystic fibrosis: a sensitive indicator of exocrine pancreatic dysfunction. Pediatr Res 1981; 15: 1351-5.

6 Elias E, Redshaw M, Wood T. Diagnostic importance of changes in circulating concentrations of immunoreactive trypsin. Lancet 1977; ii: 66-8.

7 Gillard BK, Cox KL, Pollack PA, Geffner ME. Cystic fibrosis serum pancreatic amylase. Am J Dis Child 1977; 138: 577-80.

8 Geokas MC, Brodrick JW, Johnson JH, Largman C. Pancreatic elastase in human serum. Determination by radioimmunoassay. J Biol Chem 1977; 252: 61-7.

9 Shwachman H, Diamond LK, Oski FA, Khaw KT. The syndrome of pancreatic insufficiency and bone marrow dysfunction. J Pediatr 1964; 65: 645-63.

10 Sato M. Yamamato K, Mayama H, Yamashiro Y. Exocrine pancreatic function in diabetic children. J Pediatr Gastroenterol Nutr 1984; 3: 415-20.

11 Stafford RJ, Grand RJ. Hereditary disease of the exocrine pancreas. Clin Gastroenterol 1982; 11: 141-70.

12 Cleghorn G, Benjamin L, Corey M, Forstner G, Dati F, Durie P. Age related alterations of immunoreactive pancreatic lipase and cationic trypsinogen in young children with cystic fibrosis. J Pediatr 1985; 107: 377-81.

13 Durie PR, Forstner GG, Gaskin KJ, Moore DJ, Cleghorn GJ, Wong SS, Largman C. Age-related alterations of immunoreactive pancreatic cationic trypsinogen in sera from CF patients with and without pancreatic insufficiency. Pediatr Res 1986; 20: 209-13.

14 Jacobson DG, Curington C. Connery K, Toskes PP. Trypsin-like immunoreactivity as a test for pancreatic insufficiency. N Engl J Med 1984; 310: 1307-9.
15 Van der Kamer JH, Huinink HTB, Weyers HA. Rapid method for determination of fat in feces. $J$ Biol Chem 1949; 177: 347-55.

16 Fomon SJ, Ziegler ER, Thomas LN, Jensen RL, Filer LJ. Excretion of fat by normal full term infants fed various milks and formulas. Am J Clin Nutr 1970; 23: 1299-313.

17 Regan T, DiMagno EP. Exocrine pancreatic insufficiency in celiac sprue, a cause of treatment failure. Gastroenterology 1980; 78: 484-7.

18 Frier BM, Saunders JHB, Wormsley KG, Bouchier IAD. Exocrine pancreatic function in juvenile-onset diabetes mellitus. Gut 1976; 17: 685-91.

19 Gaskin KJ, Durie PR, Corey M, Wei P, Forstner GG. Evidence for a primary defect of pancreatic $\mathrm{HCO}_{3}^{-}$ secretion in cystic fibrosis. Pediatr Res 1982; 16: 554-7.

20 Dyck WP. A titrimetric measurement of fecal trypsin and chymotrypsin in cystic fibrosis with pancreatic exocrine insufficiency. Am J Dig Dis 1967; 12: 310-7.

21 Seligson D, Marino J, Dodson E. Determination of sulfobromophthalein in serum Clin Clin Chem 1957; 3: 638-45.

22 Geokas MC, Largman C, Brodrick JW, Johnson JH. Determination of human pancreatic cationic trypsinogen in serum by radioimmunoassay. Am J Physiol 1979; 236: E77-83.

23 Gaskin KJ, Durie PR, Lee L, Hill R, Forstner GG. Colipase and lipase secretion in childhood-onset pancreatic insufficiency. Delineation of patients with steatorrhea secondary to relative colipase deficiency. Gastroenterology 1984; 86: 1-7.

24 McLaren DS, Read WWC. Classification of nutritional status in early childhood. Lancet 1972 ; ii: 146-8.

25 Durie PR, Forstner GG, Gaskin KJ, Weizman Z, Kopelman HR, Ellis L, Largman C. Elevated serum immunoreactive pancreatic cationic trypsinogen in acute malnutrition: evidence of pancreatic damage. J Pediatr 1985; 106: 233-8. 